Article

\title{
Carbon Neutral by 2021: The Past and Present of Costa Rica's Unusual Political Tradition
}

\author{
Julia A. Flagg
}

Sociology Department and Environmental Studies Program, Connecticut College, New London, CT 06320, USA; julia.flagg@conncoll.edu; Tel.: +1-860-439-2522

Received: 19 October 2017; Accepted: 15 January 2018; Published: 24 January 2018

\begin{abstract}
Costa Rica has pledged to become the first nation to become carbon neutral. This event raises the important question of how to understand this contemporary form of climate politics, given that Costa Rica has made an almost negligible contribution to the problem of global climate change. To understand this pledge, a case study spanning about 200 years situates the pledge within the country's unique historical profile. An analysis of interview data, archival research, and secondary data reveals that the pledge is the latest instance in Costa Rica's unusual political tradition. This political tradition dates back to the area's experience as a Spanish colony and as a newly independent nation. Several events, including the abolition of the army, the work on green development, and being awarded a Nobel Peace Prize were all foundational in forming Costa Rica's tradition as a place that leads by example and stands for peace and protection of nature. The carbon neutral pledge extends the political tradition that has been established through these earlier events. This case highlights the importance of understanding contemporary environmental politics through an analysis of long-term, historical data.
\end{abstract}

Keywords: Costa Rica; mitigation; carbon neutral; political tradition; environment; army; peace; case study

\section{Introduction}

In 2007, political elites in Costa Rica pledged to make the country the first in the world to become carbon neutral, or to emit net zero carbon emissions [1]. This decision seems somewhat unusual, given Costa Rica's nearly negligible contribution to the production of greenhouse gas emissions in recent years [2]. Insights from paleoenvironmental studies also indicate the country's history of abundant, and relatively stable, biodiversity and environmental conditions over recent millennia [3-5]. Through a historical case study, this paper situates Costa Rica's pledge within a longer historical narrative linking environment and society. To do so, this paper weaves together analyses of secondary data, interview data with key stakeholders in government, industry, science, and civil society, and historical documents. The analysis of these data reveals that Costa Rica's pledge represents another instance in the country's unusual "political tradition" [6] (p. 113). This paper describes the historical sources of this tradition, the more contemporary events that embody this tradition, and, through a narrative explanation, the ways in which the carbon neutral pledge represents yet another event in Costa Rica's political tradition of pursuing actions that highlight the country's democratic stability and environmental protection.

This paper is divided into several parts. The first section provides a historical background of the country, starting with its experience as a Spanish colony and tracing how elites came to provide generous public goods to its citizens. This historical experience set Costa Rica on a path toward making very different kinds of decisions about political and economic development from its neighbors. The second section explains the circumstances under which several events that have been foundational 
in the development of a contemporary political tradition in Costa Rica took place. These events are the abolition of the army, the work on "green" development, and receiving a Nobel Peace Prize. These events were influenced by Costa Rica's colonial experience and its experience as a newly independent nation. All of these events further established Costa Rica as a country that pursues seemingly iconic actions to promote peace and environmental protection without waiting for other countries to set a precedent. The third section explains the circumstances under which elites adopted the carbon neutral pledge and discusses the connections key stakeholders saw between the pledge and the country's earlier, seemingly iconic actions. The final section reviews the findings and discusses the broader relevance of the work. This case study spans nearly 200 years and reveals that the pledge can only be understood within the unique historical profile of the country. This research illustrates the centrality of environmental, political, and social history in an understanding of contemporary human-environment interactions.

\section{Materials and Methods}

The analytic approach of "process-tracing", as described by George and McKeown [7] is used to construct this narrative. This approach can help identify the intentional actors involved in a process, reconstruct how they arrived at particular junctures, identify and order the steps they took, and "develop a theory of action" [7] (p. 35). This research is an example of a "within-case analysis" [4] (p. 23), meaning that a single case of a carbon neutral pledging nation is studied over time. Though a single case study may have shortcomings in terms of generalizability, even studies of single cases have dynamism as scholars study these cases over time [8]. This current focus on Costa Rica stretches over 200 years, so concerns about the limited theoretical utility of the case should be minimized. The analysis traces events and processes over this 200-year period, and organizes each event as "a step in a causal chain" leading up to the outcome of interest-the carbon neutral pledge [9] (p. 177).

Interviews were conducted in August 2013 and July 2015 in San José, Costa Rica. Initial respondents were recruited from the Department of Climate Change in San José, Costa Rica, an extension of the Ministry of the Environment and Energy (MINAE). Each interviewee was asked to suggest other key stakeholders for interviews; thus, a snowball sample was assembled. Interviews were conducted in Spanish, English, or a combination of both languages. For the purposes of this paper, author-supplied translations of documents and interview data have been included. Archival research took place before, during, and after fieldwork, and consists of analyses of government reports, newspaper articles, and politicians' speeches.

A total of 22 interviews were conducted with 20 respondents. Two key informants were interviewed during the initial fieldwork in 2013 and again in 2015 to provide an update on work on the carbon neutrality pledge and to acquire contact information for additional interviewees. Interviewees come from the fields of government, science, industry, and civil society, though several had worked in more than one of these fields over the course of their careers. Despite not falling neatly into one of these four categories, on the recommendation of interviewees, some additional stakeholders were interviewed. These figures include a representative from AECID, the Spanish Agency for International Development Cooperation, which helped finance the carbon neutrality initiative, several academics (some of whom were involved in the initial work on carbon neutrality, and others who have written about the pledge), and a representative from INTECO (the Costa Rican Institute of Technical Norms). Interviews were not recorded because the sample includes political figures, some of whom were still in office at the time of the interview. The presence of a recorder may have led potential interviewees to decline the interview or to alter their comments. Thus, notes were hand-written by the author during each interview and were then typed up as field notes. 


\section{Results}

\subsection{Historical Context}

This first section provides a brief historical overview of Costa Rica's experience as a Spanish colony and a newly independent nation. Costa Rica's experience during this time period provided the foundation for the development of the country's political tradition. Costa Rica was isolated and the "poorest" of the Spanish colonies [10] (p. 5). The territory's lack of both a large, organized indigenous society and valuable natural resources led the Spanish to largely avoid the area now recognized as Costa Rica [11,12]. Costa Rica's isolation endured even after national independence was won in 1821. In the immediate post-independence years, Costa Rica, El Salvador, Honduras, Guatemala, and Nicaragua formed the Federation of Central America [13]. Costa Rica endured as an isolated area of this regional political union, which worked to the country's advantage. According to Mahoney [12] (p. 193), " ... while all of the other provinces quickly became engulfed in warfare and political chaos, Costa Rica escaped such devastation and made tentative economic strides forward". Thus, Costa Rica's isolation during the Federation years enabled the country to avoid involvement in internecine war that came to consume the isthmus.

Costa Rica's isolation, and the associated benefits, endured after the collapse of the Federation in 1838. Again Mahoney [12] (p. 193) writes that Costa Rica's " . . autonomy enabled it to avoid the conservative resurgence that bolstered colonial heritages and blocked liberal progress among all the other Central American countries". The political period in the immediate post-Federation years instead brought about "state-centralization measures", including the creation of laws to protect rights and the rapid expansion of coffee exports [12] (p. 193). The military was also fundamental in strengthening the central state during the 19th century [14]. The coffee exports of this time and the associated wealth they created were enjoyed by a large class of small landholders in Costa Rica, a situation that was highly unusual for the Latin American context at this historical moment. Following independence, land ownership in nearby countries came to be centralized in the hands of a few private individuals [15] (p. 63). By contrast, the Costa Rican government divided communal land into private property and distributed it to small landholders [12] (p. 193). (In the early 1800s, before coffee, privatization of land was uncommon because land was perceived to be plentiful $[16,17]$. All members of society, including wealthy ones, grew crops on either communal lands or "unclaimed forest" [17] (p. 116).) In this way, the existence of open land created the opportunity for widespread economic opportunity and stalled the development of hierarchy, as has been the case in other frontier contexts [18]. The government's redistribution of open land had a leveling effect on the class structure, with Costa Rica having a large class of small landowners and small-scale coffee producers through to the 1950s [12,15,17,19]. These reforms would take shape in other Central American countries, but not until several decades later [12].

Historically, the elites that have existed in Costa Rica have made their wealth from processing coffee, not from the producing or land-owning, part of the coffee industry [15]. Research shows that the existence of a land-owning elite can present a formidable challenge to democracy [15]. Thus, the absence of a landed elite in Costa Rica has enabled the development of good governance and the continuation of a stable democracy.

This class structure fostered elites' ability to provide generous public goods for two reasons. First, elites were providing goods to people who tended to be similar to themselves. Second, elites anticipated that the goods they provided would improve the lives of most members of society, not just a portion of society [12] (p. 194). Again, elites' investment in the public good was expected to have a leveling effect on society. In the mid to late-1800s, the government created a commercial bank, a land registry, a system to provide credit to farmers, systems of justice, invested in infrastructure [12] (pp. 193-194) and established a comprehensive system of free public education [20] (p. 88). Consequently, Costa Rica became an early leader in measures of human development [12] (pp. 193-194). Costa Rica outpaced its neighbors in the proportion of resources it invested in education at this time, and elites used the 1921 centennial celebration to show off its achievements in the educational system [21]. A pattern of public 
good provision continued into the first half of the 20th century, with the creation of a social security system [20] (p. 93) and amendments made to the constitution in support of workers' rights [14,22].

The research reported so far has illuminated several historical factors and events that shaped the development of Costa Rica's political tradition. The country's geopolitical isolation both before and after independence helped it avoid the warfare and subsequent conservative pivot that consumed its neighbors, and allowed Costa Rica to instead pursue liberal reforms. In this context, elites divided communal land into private property, thereby creating an economy with a large group of small landholders and limiting the development of a powerful landed elite. Elites invested in the public good since these investments could "lift up" many members of society, not just a select few. This historical background set the stage for several events that have been foundational in the development of an unusual political tradition in Costa Rica. An analysis of the conditions under which these events took place is the focus of the next section.

\subsection{Event Structure}

This section describes the circumstances surrounding three events in Costa Rica that have been foundational in the development of the contemporary political tradition in Costa Rica. These events include the abolition of the army, the work on "green development", including the initial forestry law and subsequent efforts to stall deforestation, and receiving a Nobel Peace Prize. These events were influenced by the conditions described above (geopolitical isolation, relatively egalitarian agricultural economy, and elites' investment in public goods). All of these events established Costa Rica as a place that stands for peace, democracy, and nature. The 2007 carbon neutral pledge builds on this narrative for which Costa Rica has come to be known.

\subsubsection{First Event: Abolishing the Army}

One significant event that is part of the trajectory leading up to the carbon neutral pledge is the government's decision to abolish the army after a brief civil war. The 1948 presidential election featured a run off between experienced, Conservative politician Rafael Ángel Calderón and “Conservative newspaper publisher" Otilio Ulate [20] (p. 93). In response to the election results, which showed that Ulate had won, the "Calderonista majority in the Assembly voted to annul the election on grounds of fraud", [20] (p. 93-94). This upset the Social Democratic party, and one of its key members, José Figueres, who believed Ulate was the rightful victor of the election and leader of the country $[14,20]$. This provided the fodder for a civil war. When the Assembly tried to annul the election Figueres marched on the capital of San José with a 600-man army that he had trained at his rural home [14]. The fighting ended soon after, but not before causing between 1000-2000 casualties, mostly on the government army's side [14]. President-elect Ulate and Figueres subsequently signed a pact, which left Figueres in charge of the country for 18 months and made Ulate president after that time. As part of this pact, a commission to draft a new constitution was appointed. Continuing the 19th century pattern of public good provision, the new constitution included several generous provisions, many of them about workers' rights [14,22].

The new constitution also abolished the army. According to Hoivik and Aas [14] (p. 342), the decision to abolish the army originated with several young men affiliated with Figueres's Social Democratic Party, who saw the abolition of the army as "... an integral part of a modernized Costa Rican state." The abolition of a national army in any context is unusual, as the military represents one critical pillar of state power [23]. The Costa Rican army had played a critical role in the development of central state power during the 19th century [14]. However, an analysis of the Costa Rican decision reveals several forces that made the decision to abolish the army relatively uncontroversial.

First, the army was small and weak: it had just been defeated by an army that was developed at one man's home. Second, Costa Rica's pattern of relying on military assistance from the United States on prior occasions undermined the sovereignty of its own army [14]. In other words, maintaining an army was not worth it. Third, the abolition of the army builds on the political tradition of investing 
in public goods. Freeing up funds from military costs enabled the government to more heavily invest in education and natural resource protection [10] (pp. 27, 155) [24], a pattern that holds up across developing nations [25]. Edelman and Oviedo [24] (p. 23) explain that the Figueres-led junta "abolished the army in order to forestall a conservative restoration and to free up resources for social programs". They add that although "security-related expenditures" grew through the 1980s, Costa Rica maintained "one of the lowest ratios of military to social welfare spending of any country in the world" [24] (p. 30). The abolition of its army was foundational in establishing Costa Rica's place in the world as a peacekeeping nation that leads by example. According to Hoivik and Aas [14], there are several components of demilitarization, only one of which is the ideology of demilitarization. However, they conclude that Costa Rica scores very highly on this particular dimension, since the "abolition of the army is often mentioned as a sign of the essential peacefulness of the country" [14] (p. 350).

\subsubsection{Second Event: Green Development}

Costa Rica is also well known for its work in the area of environmental protection. The 1969 forestry law and the 1996 establishment of a Payments for Environmental Services (PES) program are the critical events in Costa Rica's work in the area of "green development". The pace of deforestation in Costa Rica increased dramatically post-1950 and by the early 1980s, Costa Rica had the highest deforestation rate in the world at about $4 \%$ of land deforested per year $[10,26-30]$. The production of beef for international markets fueled the rapid rise in Costa Rica's rate of deforestation at this time [26]. Government made several isolated attempts to slow deforestation, but it was not until 1969, that the government passed a forestry law [10]. The authors of the legislation looked to forestry laws of larger, dissimilar countries, including Venezuela, Mexico, and the United States, in drafting a law for Costa Rica [10] (p. 65). The law included protections for wildlife, promoted environmental education, set standards for the destruction of forests, and created the national parks department in the Ministry of Agriculture and Livestock [10] (pp. 66, 72). It aimed to curtail deforestation by making reforestation tax-deductible [31] (p. 1); however, its greatest area of success was in establishing national parks and biological reserves [10] (p. 71). In subsequent years, Costa Rica came to be known as a pioneer in the "biocultural" approach to land management [32].

By itself, the law did not dramatically curtail deforestation rates; in fact, significant deforestation has occurred since the passage of the law [10]. Despite this, the forestry law is a critical event in the development of Costa Rica's unusual political tradition for several reasons. First, the law symbolizes the Costa Rican government's move from a relatively hands-off land management approach and toward an "interventionist regime" of land management that characterized the 1970s and 1980s [27], see also [33] (p. 72). This interventionist approach included government's decisions in subsequent years to pay squatters to leave protected, public lands [10] (p. 77), [34] (p. 96). Second, the law illustrates that political leaders in Costa Rica did not wait for other, similar countries to set a precedent in land management; instead, leaders set their own precedent of state-led environmental protection. Again, authors of the plan consulted plans from dissimilar countries before drafting a plan for the Costa Rican context [10]. Third, the law provided a starting point for subsequent work on forestry, including the work from the 1990s on the Payments for Environmental Services program [29,35].

In the decades following the 1969 law, government used various means to establish financial benefits for reforestation [31]. However, by the mid-1990s, the government could no longer provide subsidies through certificates to land owners because of stipulations in the country's structural adjustment programs [29]. In this context, the government began a Payments for Environmental Services (PES) program in 1996 as part of its fourth national forestry law [29,31]. FONAFIFO, the National Forestry Financing Fund, oversaw and managed the program $[29,31,35,36]$. Under the PES program, the government compensates private landholders for the services that their lands provide. Four services are recognized: mitigation of greenhouse gas emissions, hydrological services, biodiversity conservation, or scenic beauty [29,31,35-37]. Initial funds to pay landowners came from a tax on fossil fuels and additional support came from the World Bank and the Global Environmental Facility $[35,37,38]$. 
The PES program did not, on its own, solve the problem of deforestation. By the time the PES program was established, Costa Rica already had about 25 percent of its land area in protected spaces $[10,29]$. By the mid-1980s, deforestation rates were dropping because of a decline in beef prices on international markets $[10,28]$. The decline in beef prices made the clearing of forests for the production of beef a less financially attractive option. However, there are three reasons why the creation of the PES program is a critical event in the development of an unusual political tradition in Costa Rica. First, Costa Rica developed this program early in comparison to other developing nations [37], and developed the most "elaborate" PES program in Latin America [39]. As with the forestry law, Costa Rican political elites developed and used the PES program without waiting for other countries to set a precedent. Second, the Costa Rican government has invested in the program at a level unmatched by other countries. As Daniels et al. [29] (p. 2118) explain, within the first ten years of the PES's existence, the country invested $0.43 \%$ of its annual budget in the program. Costa Rica's immense financial commitment to the program illustrates elites' level of commitment to it. The authors add, "Nominally influencing land use management through positive incentives, as opposed to regulatory land use restrictions, on such a large fraction of privately-held land may be unparalleled in the world" (emphasis added) [29] (p. 2118). Third, the PES program symbolizes political efficacy in having "dealt" with the problem of deforestation. It illustrates that Costa Rica was "out front" in responding to land use change. Costa Rica is often heralded as a success story for PES [31] and the country's program has served as a model for other countries' programs [40,41].

The establishment of the PES program is similar to the abolition of the army. As the earlier section demonstrated, the army was abolished (in part, at least) because the army was small and weak and because Costa Rica received consistent military support from the US. The confluence of these factors enabled the country to abolish the army, a feat that would be difficult in almost any other context. Rather than being an isolated event, the PES program is part of a trajectory of financial incentives to remedy land use problems in the country $[29,35]$. By the time the PES program started, the worst of the deforestation problem was over. The PES program, like the abolition of the army, illustrates to an international audience Costa Rica's priorities of protecting nature and investing in the public good.

\subsubsection{Third Event: Nobel Peace Prize}

President Óscar Arias Sánchez's 1987 Nobel Peace Prize, like the abolition of the army and the creation of the PES program, further established Costa Rica as a country with a history of taking on exceptional political actions that appeal to an international audience. Arias, a descendant of the country's coffee elite, ran on a platform of peace in the 1986 presidential election and won the election by a narrow margin $[15,42]$. Subsequently, Arias became involved in the Central American peace process. In February 1987, Arias proposed what became known as the "Arias Peace Plan", which recognized all governments of Central America and called for the abatement of support to rebel groups, including the contras in Nicaragua [15] (pp. 42-43). Following the 1979 overthrow of the Somoza dictatorship by the Sandinistas, Nicaragua became a "revolutionary socialist state" [15] (p. 5). The Contra-Sandinista conflict raged both before and after the signing of the peace treaty in Nicaragua [43]. El Salvador experienced a civil war and several military dictatorships. On 7 August 1987 the presidents of Costa Rica, Nicaragua, Honduras, Guatemala, and El Salvador signed the agreement and aimed to secure peace throughout the region $[44,45]$.

According to Wehr and Lederach [43], Arias and the presidents of Guatemala (Vinicio Cerezo) and Nicaragua (Daniel Ortega) helped make the peace process a reality. Arias oversaw the event and mediated the countries' involvement, Cerezo agreed to host the treaty-signing event and lobbied for Nicaragua's inclusion, and Ortega made "important concessions" in the process [43] (p. 90). Despite five presidents' involvement and the key leadership of three of them, Arias was the only one to be awarded the 1987 Nobel Peace Prize. Arias was no doubt "central" to the process [43] (p. 90), but the extent to which he was seen as the only deserving candidate of the prize is less clear. 
Arias's Nobel Peace Prize, like the abolition of the army, original forestry law, and creation of the PES program, is another critical event in the development of Costa Rica's unusual political tradition. There are several reasons for this. First, Arias was the first Central American to be awarded a Nobel Peace Prize [46]. This further established Costa Rica's position as a beacon of democracy and stability in Central America, with authors subsequently calling Costa Rica the "Switzerland of Central America" [47]. Second, and relatedly, the Nobel Peace Prize helped usher in a dramatic rise in tourism. Beginning in the late 1980s, international tourism rates to Costa Rica increased dramatically. According to Honey, Vargas, and Durham [48] (p. 16), "Between 1989 and 1994, international tourism more than doubled, from 376,000 to 761,000 ." The majority of this growth was seen in a particular style of tourism, ecotourism, which attracted people who were interested in hiking and other outdoor experiences. By 1993, tourism surpassed traditional exports, such as coffee and bananas, to become the industry that contributed the most to the economy [49]. This dramatic rise in tourism was due to a confluence of events. The country's proximity to the United States, democratic tradition, leadership in human development indicators, and reasonable infrastructure made Costa Rica an attractive location [48] (p. 16). Once Arias was awarded the Nobel Prize, tourists noticed the country as a safe and stable place in which they could visit rainforests.

What is exceptional about this rise in international tourism is that this was a time when international tourism in Central America was unpopular. According to data from 1995, Costa Rica far surpassed its Central American neighbors and some larger countries in South America in annual international tourist visits (Costa Rica: 785,000; Belize: 131,000; Ecuador: 440,000; El Salvador: 235,000; Guatemala: no data; Honduras: 271,000; Nicaragua: 281,000; Panama: 345,000; Peru: 479,000) [50]. Amid the civil wars and crises of the late 1980s in Central America, Costa Rica stood out as a symbol of democratic stability and peace.

The abolition of the army, the nation's work on green development, and being awarded a Nobel Peace Prize are critical events in the development of Costa Rica's unusual political tradition. All of these events helped define the kind of place Costa Rica is.

\subsection{Carbon Neutrality}

This section describes the conditions under which Costa Rica's pledge was adopted and how interviewees saw the carbon neutral pledge as a further development in the country's unusual political tradition. Óscar Arias Sánchez began his second presidential term in May 2006 and by the end of the year, his government had started to work on the idea of creating a "Peace with Nature" political coalition. According to the leader of this coalition, the idea of establishing peace with nature originated with the late Alvaro Ugalde, former head of the country's national parks system. Arias and Ugalde had known each other since the late 1970s when they served on a strategic committee about the national parks. According to this respondent, in 2006, Ugalde met Arias on a plane and said to him, "you know, you brokered peace in Central America" during your first presidency, "why not broker peace with nature during your second?" (Author's interview field notes 16 July 2015).

In early December 2006, the president declared, in the public interest, the initiative "Peace with Nature" [51]. In addition to calling the broad, new government-initiated agenda "Peace with Nature", Arias and his advisors also established a 30-person committee called "Peace with Nature", to execute the carbon neutral pledge (Author's interview field notes 16 July 2015) [52]. Several officials associated with this coalition, along with others, began to write a national plan on climate change in 2007 and finished it in 2009. This "National Strategy on Climate Change" describes the country's dual focus on national and international agendas on climate change, as well as its plan for carbon neutrality [53]. The national agenda includes six primary areas of focus: (1) mitigation, (2) adaptation, (3) metrics, (4) development of capacities and technological transfers, (5) public sensitivity, education, and culture, and (6) finances. This indicates that while mitigation is a clear area of focus in the national strategy, it is not the only national climate priority. Within the area of mitigation, three sub-goals are articulated: (1) the reduction of greenhouse gas emissions by source, (2) carbon capture and storage, and (3) the 
development of a national carbon market. Within the first sub-goal (the reduction of greenhouse gas emissions by source), eight key sectors for emission reductions are identified: (1) energy, (2) transport, (3) agriculture and livestock, (4) industrial, (5) solid wastes, (6) tourism, (7) water, and (8) land use change [53] (p. 48).

There are some important omissions from this section. The primary driver of Costa Rica's economy is international tourism, yet, the greenhouse gas emissions generated from tourists' air travel are not mentioned in the sectors on transport or tourism [53] (p. 49-51). In addition, the section on energy generation prioritizes almost exclusively the development of renewable energy. Costa Rica's energy portfolio was already drawn almost exclusively from renewable sources. Thus, while achieving carbon neutrality is more feasible in such a context, it is interesting to note that the national plan prioritizes the development of even more renewable energy rather than taking up questions about the overall use of energy.

Although even prior to its work on carbon neutrality, Costa Rica was known for its dependence on renewable energy and its weak reliance on fossil fuels, recent news articles suggest great interest in further developing Costa Rica's highway transportation systems [54,55]. These are likely to be very fossil fuel intensive projects. Overall, an analysis of this national strategy reveals that the plan is both very broad, and perhaps by consequence, somewhat vague. By trying to capture so many different climate goals across so many different sectors, specific, and major, contributors to emissions may be excluded.

Although carbon neutrality is a national goal, government has encouraged individual institutions at sub-national scales to become carbon neutral (Author's interview field notes 6 July 2015) [53]. The original target for becoming a carbon neutral nation was set at 2021, the same year as the country's bicentennial celebration of independence [53]. Interviewees explained that the 2021 target was selected for celebratory and symbolic reasons, rather than scientific ones (Author's interview field notes 8 July 2015; 14 July 2015; 15 July 2015). However, other research has illustrated that while Costa Rica's pledge began largely as a symbolic commitment, over time the pledge has taken on substance that may lead to emission reductions [56]. Following norm INTE.12.016, businesses follow three steps to become carbon neutral. First, a business develops an inventory of its emissions. Second, a business takes steps to reduce emissions. Third, a business pays FONAFIFO to offset the emissions that it continues to emit, even after taking steps to reduce emissions (Author's interview field notes 15 July 2015; 22 July 2015).

Insights from Interview Data

Interviewees often mentioned how the historical profile of Costa Rica (as discussed in Section 3.1) catalyzed the work on carbon neutrality. A university official involved with carbon neutrality verification processes said that Costa Rica is more "open" to something like a carbon neutrality pledge because of the country's historical legacy of democracy and the population's high level of education. He added that democracy is a political style that "permits sensibility with respect to environmental issues," (Author's interview field notes 10 July 2015). A different respondent, a biologist, government consultant, and civil society member, expressed similar views about the importance of Costa Rica's past with respect to its carbon neutral pledge. When asked why he thought Costa Rica was the kind of place that would make a carbon neutrality pledge, he started by explaining the kinds of places that would not make a pledge. It would be impossible, he said, to make a carbon neutrality pledge in countries such as Chile or Nicaragua. It would be impossible in countries with armies or in countries where hunger is the main issue, such as countries in Africa. As he put it, it is never going to happen there. He went on to say you do not need to be a developed country, because "we're not", but you've got to have certain things, such as human rights and water, to make a carbon neutral pledge. For emphasis, he added, "it is not going to happen in Haiti". Finally, he said that things happen in Costa Rica that do not happen elsewhere, like the elimination of the army (Author's interview field notes 13 July 2015). His words make clear that he, like others, attributed these unusual events in Costa Rica's past to its historical profile that developed in the nineteenth and early twentieth centuries. 
In addition, some interview and archival data reveal the relevance that Costa Rica's actions throughout the twentieth century, including the abolition of the army, the work on green development, and being awarded a Nobel Peace Prize, had to the carbon neutral pledge. For example, several days after making a national announcement about the carbon neutrality pledge in San José, former President Arias published an article in Costa Rica's major national newspaper, La Nación. In the article, he makes an explicit comparison between achieving carbon neutrality and both the abolition of the army and his own Nobel Peace Prize. He even goes as far as to use the very same word (abolish/abolir) to draw a connection between achieving carbon neutrality and eliminating the army. He claims, "Abolishing net carbon will be, for us, the equivalent of the abolishment of the army that Don Pepe [Figueres] did and the pacification of Central America, which we achieved during my first presidency" [57]. His comments here position the carbon neutral pledge as the next event in Costa Rica's unusual political tradition, building on the abolition of the army and the 1987 Nobel Peace Prize.

Two interviewees who were involved at the highest political levels with the development of the carbon neutral idea and writing the carbon neutral national strategy saw the pledge as a way to bolster the nation's efforts to encourage reforestation and slow deforestation. As discussed above, in the early 1990s the government put a tax on gasoline and the funds went to FONAFIFO. Then FONAFIFO used this money to pay landowners if their land provided any one of four possible services. Several interviewees said that FONAFIFO "worked" and that by the early 2000s, the country had recuperated forest. Thus, there was interest in the continuing existence of the program. However, by 2006-2007, interviewees said that the initial budget in FONAFIFO (that came from the tax on fossil fuels) was exhausted and the country had to pursue other sources of funding (Author's interview field notes 8 July 2015; 13 July 2015). Other sources confirm that FONAFIFO's funds have been insufficient to pay landowners over time $[41,58]$. Since part of the process of a business becoming carbon neutral involves paying FONAFIFO to compensate for remaining emissions (described above), the carbon neutral norm was a way to boost funding for FONAFIFO and thus bolster preexisting national forest protection efforts.

Several other interviewees described how events in Costa Rica's history of green development led to the work on carbon neutrality. Though not specifically tied to the 1969 forestry law or the development of the payments for environmental services program, one interviewee claimed that the carbon neutrality goal was necessary because other available mechanisms for mitigation, including the Clean Development Mechanism (CDM) from the Kyoto Protocol were not useful in Costa Rica. A government official involved at the highest levels with the national work on carbon neutrality explained that the CDM had "limitations" for making progress on mitigation in Costa Rica. This is because (according to him) the two factors that the CDM can address are the generation of clean electricity and deforestation. In both of these themes, Costa Rica "has advanced" beyond other developing countries because by the time the CDM was created to help establish clean energy projects and slow deforestation in developing countries, Costa Rica had already tackled these issues. He added, "business as usual" in Costa Rica already involved a lot of renewable energy and reforestation. He added that because we couldn't get much out of the CDM, we did carbon neutrality: "We needed our own plan," (Author's interview field notes 6 July 2015). A university professor with prior experience working in government articulated how Costa Rica's prior successes in green development made the unusual carbon neutrality pledge a necessity. The country's success with reforestation efforts and the development of renewable energy portfolio (about 98\%), left Costa Rica in a position where it "needed something to push the agenda", since the functions of Kyoto did not work in the country (Author's interview field notes 8 July 2015).

\section{Discussion}

The carbon neutral pledge is best understood as the latest in a long line of seemingly exceptional actions that Costa Rican elites have undertaken. Thus, the carbon neutral pledge builds on and extends the unusual Costa Rican political tradition. First, the pledge builds on themes established with the 
elimination of the army. It is worth recalling that some of the rationales given for the elimination of the army is that the army was small and weak [14]. There was thus little opposition to the idea of abolishing this depleted institution. In this sense, there was little to lose by eliminating the army. There are parallels between the ease with which the army was eliminated and the ease with which the carbon neutral pledge was made. Because Costa Rica's pledge is a voluntary national commitment that was not overseen by a governing agency in the years immediately following the commitment, "going" carbon neutral was a very low cost political commitment. Costa Rica really cannot lose by going carbon neutral.

The carbon neutral pledge also builds on some of the central tenets established with the 1969 forestry law. Again, passage of this law signaled the government's move into the "interventionist period" of the 1970s and 1980s [27], when government became more directly involved in forestry protection and environmental oversight. The passage of this law stands out because it showed that Costa Rica did not wait for other countries to set a precedent in forestry laws. In addition, the forestry law provided the legal basis for subsequent work. The carbon neutral pledge also displayed an unwillingness to wait for other countries to set a precedent for carbon mitigation. As the world's first country to make a carbon neutral pledge, the country set a precedent for others to follow. Several other nations have since made identical pledges [1].

In addition, the carbon neutral pledge provided a starting point for later work on climate change. All countries were called upon to make Intended Nationally Determined Contributions (INDCs) ahead of the 2015 Conference of the Parties (COP) meeting in Paris. In its INDC, Costa Rica reaffirmed its commitment to become a carbon neutral country, albeit by a later date (2085) [59]. While the pushback of the target end date might be a sign of declining national ambition in the country around the theme of carbon neutrality, as of 2015, there was still enthusiasm for the government's continuing work on carbon neutrality (Author's interview field notes 6 July 2015). It is possible that the new end date reflects a more realistic, more scientifically based target end date for achieving carbon neutrality. As several interviewees described, the initial target of 2021 was chosen for its cultural and political importance, not because research showed that the country could achieve the goal by this date. The carbon neutral pledge served as a starting point for the future national climate pledge in a way that is similar to how the initial forestry law was part of a trajectory for subsequent work on forestry and environmental services.

The carbon neutral pledge also shares some common characteristics with the PES program. Again, Costa Rica developed its PES program early [37] and elaborately [39] for the Latin American context. Importantly, the PES program also signals a political efficacy in having "dealt" with the problem of deforestation. There are parallels between the PES program and the carbon neutral pledge, with Costa Rica again standing out as a regional leader in climate mitigation issues. As of September 2017, Climate Action Tracker ranked Costa Rica as the only Latin American country that has national policies in line with keeping the globe to a 2-degree Celsius increase [60]. In addition, in 2014, Costa Rica was the most highly ranked Central American country in its preparedness for climate adaptation [61]. The carbon neutral pledge also illustrates a common theme in Costa Rican politics-a tendency to set a precedent, rather than to wait for one to be established, and to take pride in having done so. Several interviewees took pride in knowing that Costa Rica was the first country to pledge to become carbon neutral (Author's interview field notes 8 July 2015; 14 July 2015), though some were happy knowing that Costa Rica was one of the first (Author's interview field notes 10 July 2015). This was even true at the level of individual businesses, with several pointing out that they were one of the first industries in the country to become carbon neutral (Author's interview field notes 1 August 2013; 21 July 2015), or the first company in a particular city to become carbon neutral (Author's interview field notes 21 July 2015).

The pledge, like the Nobel Peace Prize, also has the potential to reinvigorate the national tourism industry. With airlines, hotels, and rental car companies all pledging to become carbon neutral [62], 
the pledge has created opportunities for the continued growth of ecotourism that is purported to have a small carbon footprint.

The research reported on here has shown that the carbon neutral pledge is the latest in a long line of seemingly exceptional actions undertaken by the Costa Rican state. These actions, including the abolition of the army, the work on "green development", and being awarded a Nobel Peace Prize, formed an image for an international audience about the kind of place Costa Rica is. The carbon neutral pledge reinforces the specific political narrative that has come to characterize Costa Rican history, strengthens the nation's largest industry, and bolsters the country's status as a place that is "out front" on issues that speak to the values of peace and protection of nature.

Though this work has focused on the specific case of Costa Rica, the implications are much broader. While some research in the social sciences has explored how nations' positions on climate change are influenced by the ways in which they were incorporated into the global economy [63], less research has focused on one single nation and provided a detailed historical account of how responses to global climate change build on (or fail to build on) a nation's prior achievements or experiences. Future research on nations' environmental actions can seek to embed nations' recent decisions about climate change within long-term, political narratives. This kind of work is possible, as nearly all nations have made individual commitments to address climate change. It may be possible to better understand how a country approaches the future by first understanding how it has acted in the past. In addition, political narratives can be merged with existing paleoenvironmental research i.e., [3-5] to understand nations' human-environment interactions over long periods of time. In short, future research could benefit from integrating insights from across diverse fields to better understand how humans and landscapes influence each other over time, as some researchers have started to do [64,65].

This case study illustrates the importance of using long-term historical data to understand environmental issues. Writing specifically about the use of paleoecology in the field of conservation, Davies and Bunting [66] claim that scientists could benefit from using a broader range of types of evidence as we enter a period of extreme climate variability. This period of unknown climate variability is coupled with rapid policy and social changes. More specifically, ideas about which nations ought to respond to climate change has shifted dramatically from the Kyoto Protocol era, in which the responsibility for action fell to wealthy nations, to the Paris Agreement, in which all nations were called upon to act. At the same time, the world is undergoing rapid social changes due to globalization, demographic shifts, and migration. This confluence of unknown climate variability, extensive political changes, and rapid social shifts suggests that research on contemporary climate issues would benefit from the use of more, not fewer, types of data to understand social responses to climate change. One way to do this is to situate developments in climate decisions within longer historical narratives.

Acknowledgments: This research was supported by funding from Rutgers University Departments of Human Ecology and Sociology, the Rutgers University Graduate School, and Columbia University's Hertog Global Strategy Initiative. Start-up research funding from Connecticut College support the costs to publish in open access.

Conflicts of Interest: The author declares no conflict of interest.

\section{References}

1. Flagg, J.A. Aiming for Zero: What Makes Nations Adopt Carbon Neutral Pledges? Environ. Sociol. 2015, 1, 202-212. [CrossRef]

2. Brechin, S.R. Climate Change Mitigation and the Collective Action Problem: Exploring Country Differences in Greenhouse Gas Contributions. Sociol. Forum. 2016, 31, 846-861. [CrossRef]

3. Horn, S.P. Prehistoric fires in the highlands of Costa Rica: Sedimentary charcoal evidence. Rev. Biol. Trop. 1989, 37, 139-148.

4. Horn, S.P. Postglacial vegetation and fire history in the Chirripó Páramo of Costa Rica. Quat. Res. 1993, 40, 107-116. [CrossRef] 
5. Hooghiemstra, H.; Cleef, A.M.; Noldus, G.W.; Kappelle, M. Upper Quaternary vegetation dynamics and palaeoclimatology of the La Chonta bog area, Cordillera de Talamanca, Costa Rica. J. Quat. Sci. 1992, 7 , 205-225. [CrossRef]

6. Booth, J.A.; Seligson, M.A. Paths to Democracy and the Political Culture of Costa Rica, Mexico, and Nicaragua. In Political Culture and Democracy in Developing Countries; Diamond, L.J., Ed.; Lynne Rienner Publishers: Boulder, CO, USA, 1993; pp. 107-138, ISBN 1555875157.

7. George, A.; McKeown, T. Case Studies and Theories of Organizational Decision-Making. In Advances in Information Processing in Organizations, 2nd ed.; Coulam, R.F., Smith, R.A., Jai, P., Eds.; Jai Press: Greenwich, CT, USA, 1985; pp. 21-58, ISBN 0892324252.

8. Gerring, J. What Is a Case Study and What Is It Good for? Am. Polit. Sci. Rev. 2004, 98, 341-354. [CrossRef]

9. George, A.L.; Bennett, A. Case Studies and Theory Development in the Social Sciences; MIT Press: Cambridge, MA, USA, 2004.

10. Evans, S. The Green Republic: A Conservation History of Costa Rica; University of Texas Press: Austin, TX, USA, 1999.

11. Fitch, J.S. The Armed Forces and Democracy in Latin America; The Johns Hopkins University Press: Baltimore, MD, USA, 1998; ISBN 0-8018-5917-4.

12. Mahoney, J. Colonialism and Postcolonial Development: Spanish America in Comparative Perspective; Cambridge University Press: New York, NY, USA, 2010.

13. A guide to the United States' History of Recognition, Diplomatic, and Consular Relations, by Country, Since 1776: Central American Federation. Available online: https://history.state.gov/countries/central-americanfederation (accessed on 22 October 2015).

14. Hoivik, T.; Aas, S. Demilitarization in Costa Rica: A Farewell to Arms? J. Peace Res. 1981, 18, $333-351$. [CrossRef]

15. Paige, J.M. Coffee and Power: Revolution and the Rise of Democracy in Central America; Harvard University Press: Cambridge, MA, USA, 1997.

16. Gudmundson, L. Costa Rica before Coffee: Occupational Distribution, Wealth Inequality, and Elite Society in the Village Economy of the 1840s. J. Lat. Am. Stud. 1983, 15, 427-452. [CrossRef]

17. Gudmundson, L. Peasant, Farmer, Proletarian: Class Formation in a Smallholder Coffee Economy, 1850-1950. In Coffee, Society, and Power in Latin America; Roseberry, W., Gudmundson, L., Kutschbach, M.S., Eds.; The Johns Hopkins University Press: Baltimore, MD, USA, 1995; pp. 112-150.

18. The Significance of the Frontier in American History. Available online: https://www.learner.org/ workshops / primarysources/corporations/docs/turner2.html (accessed on 16 June 2016).

19. Lehoucq, F.E. The Institutional Foundations of Democratic Cooperation in Costa Rica. J. Lat. Am. Stud. 1996, 28, 329-355. [CrossRef]

20. Peeler, J.A. Elite settlements and democratic consolidation: Colombia, Costa Rica, and Venezuela. In Elites and Democratic Consolidation in Latin America and Southern Europe; Higley, J., Gunther, R., Eds.; Cambridge University Press: New York, NY, USA, 1991; pp. 81-112.

21. Fumero-Vargas, A.P. National Identities in Central America in a Comparative Perspective: The Modern Public Sphere and the Celebration of Centennial of Central American Independence September 15, 1921. Ph.D. Thesis, University of Kansas, Lawrence, KS, USA, 2005.

22. Wilson, B.M. When social democrats choose neoliberal economic policies: The case of Costa Rica. Comp. Polit. 1994, 26, 149-168. [CrossRef]

23. Collins, R. Mann's Transformations of the Classic Traditions. In An Anatomy of Power: The Social Theory of Michael Mann; Hall, J.A., Schroeder, R., Eds.; Cambridge University Press: New York, NY, USA, 2006; pp. 19-32.

24. Edelman, M.; Oviedo, R.M. Costa Rica: The non-market roots of market success. Rep. Am. 1993, $26,22-44$.

25. Adeola, F.O. Military expenditures, health, and education: Bedfellows or Antagonists in third world development? Arm. Forces Soc. 1996, 22, 441-467. [CrossRef]

26. Augelli, J.P. Modernization of Costa Rica's Beef Cattle Economy: 1950-1985. J. Cult. Geogr. 1989, 9, 77-90. [CrossRef]

27. Brockett, C.D.; Gottfried, R.R. State policies and the preservation of forest cover: Lessons from contrasting public-policy regimes in Costa Rica. Lat. Am. Res. Rev. 2002, 37, 7-40. 
28. Daniels, A.E. Forest Expansion in Northwest Costa Rica: Conjuncture of the Global Market, Land-Use Intensification, and Forest Protection. In Reforesting Landscapes: Linking Pattern and Process; Nagendra, H., Southworth, J., Eds.; Springer: Dordrecht, The Netherlands, 2010; pp. 227-252.

29. Daniels, A.E.; Bagstad, K.; Esposito, V.; Moulaert, A.; Rodriguez, C.M. Understanding the impacts of Costa Rica's PES: Are we asking the right questions? Ecol. Econ. 2010, 69, 2116-2126. [CrossRef]

30. Nygren, A. Development Discourses and Peasant-Forest Relations: Natural Resource Utilization as Social Process. Dev. Chang. 2000, 31, 11-34. [CrossRef]

31. Payments for Ecosystem Services in Costa Rica and Forest Law No. 7575: Key Lessons for Legislators. Available online: http:/ / www.agora-parl.org/sites/default/files/090422_e-parliament_forests_initiative. pdf (accessed on 26 October 2015).

32. Janzen, D.H. Guanacaste National Park: Tropical Ecological and Biocultural Restoration. In Rehabilitating Damaged Ecosystems: Volume II; Cairns, J., Jr., Ed.; CRC Press: Boca Raton, FL, USA, 1988; pp. 143-192.

33. Miranda, M.; Dieperink, C.; Glasbergen, P. The Social Meaning of Carbon Dioxide Emission Trading. Environ. Dev. Sustain. 2002, 4, 69-86. [CrossRef]

34. Horton, L.R. Buying up nature: Economic and social impacts of Costa Rica's ecotourism boom. Lat. Am. Perspect. 2009, 36, 93-107. [CrossRef]

35. Miranda, M.; Dieperink, C.; Glasbergen, P. Costa Rican Environmental Service Payments: The Use of a Financial Instrument in Participatory Forest Management. Environ. Manag. 2006, 38, 562-571. [CrossRef] [PubMed]

36. Fletcher, R.; Breitling, J. Market mechanism or subsidy in disguise? Governing payment for environmental services in Costa Rica. Geoforum 2012, 43, 402-411. [CrossRef]

37. Pagiola, S. Payments for Environmental Services in Costa Rica. World Bank, 2006. Available online: http:/ / www.ncsu.edu/project/amazonia/for414/Readings/Pagiola_PSA2006.pdf (accessed on 9 October 2015).

38. Zúñiga, J.M.R. Paying for forest environmental services: The Costa Rican experience. Unasylva 2003, 54, 31-33.

39. Pagiola, S.; Arcenas, A.; Platais, G. Can Payments for Environmental Services Help Reduce Poverty? An Exploration of the Issues and the Evidence to Date from Latin America. World Dev. 2005, 33, 237-253. [CrossRef]

40. Fletcher, R. Making 'Peace with Nature': Costa Rica's Campaign for Climate Neutrality. In Climate Change Governance in the Developing World; Roger, C., Heldpp, D., Nag, E., Eds.; Polity Press: London, UK, 2013; pp. 155-173.

41. Pagiola, S. Payments for Environmental Services in Costa Rica. Ecol. Econ. 2008, 65, 712-724. [CrossRef]

42. Dunkerley, J. Power in the Isthmus: A Political History of Modern Central America; Verso: New York, NY, USA, 1988.

43. Wehr, P.; Lederach, J.P. Mediating Conflict in Central America. J. Peace Res. 1991, 28, 85-98. [CrossRef]

44. Oscar Arias Sanchez-Facts. Available online: https://www.nobelprize.org/nobel_prizes/peace/laureates/ 1987 / arias-facts.html (accessed on 15 June 2016).

45. Americas, Central America: Efforts toward Peace. Available online: http://www.un.org/en/sc/repertoire/ 89-92/Chapter\%208/AMERICA/item\%2009_Central\%20America_.pdf (accessed on 19 April 2016).

46. All Nobel Peace Prizes. Available online: https://www.nobelprize.org/nobel_prizes/peace/laureates / (accessed on 15 April 2016).

47. Weinberg, B. War on the Land: Ecology and Politics in Central America; Zed Books Ltd.: Atlantic Highlands, NJ, USA, 1991.

48. Impact of Tourism Related Development on the Pacific Coast of Costa Rica: Summary Report. Available online: http:/ / www.responsibletravel.org/resources/documents/coastal-tourism-documents/summary\% 20report/summary_report_-_impact_tourism_related_development_pacific_coast_costa_rica.pdf (accessed on 6 November 2015).

49. LePree, J.G. Certifying sustainability: the efficacy of Costa Rica's certificate for sustainable tourism. Flor. Atl. Comp. Stud. J. 2009, 11, 57-78.

50. The World Bank DataBank. Available online: http://databank.worldbank.org/data/home.aspx (accessed on 15 October 2015). 
51. The President of the Republic Declares the Public Interest Initiative "Peace with Nature". Available online: http:/ / www2.eie.ucr.ac.cr/ jromero/sitio-TCU-oficial/normativa/archivos/leyes_nac/Declara_ de_Interes_Publico_la_Iniciativa_Paz_con_la_Naturaleza.pdf (accessed on 4 September 2015).

52. Ponchner, D.; Vargas, A. Government will Launch the Initiative "Peace with Nature". La Nacion, 2007. Available online: http://wvw.nacion.com/ln_ee/2007/julio/04/aldea1155221.html (accessed on 25 September 2015).

53. National Strategy on Climate Change. Ministry of Environment, Energy, and Telecommunications, 2009. Available online: http:/ / cambioclimaticocr.com/2012-05-22-19-42-06/estrategia-nacional-de-cambioclimatico (accessed on 6 May 2013).

54. Arias, L. Government pledges to speed up construction of San Carlos highway. The Tico Times. Available online: http:/ / www.ticotimes.net/2015/12/10/government-pledges-speed-construction-sancarlos-highway (accessed on 14 December 2017).

55. Arias, L. Construction to begin soon to curb heavy traffic on Circunvalacion beltway. The Tico Times. Available online: http:/ / www.ticotimes.net/2016/09/08/costa-rica-heavy-traffic (accessed on 14 December 2017).

56. Flagg, J.A. From Symbol to Substance: Costa Rica's Carbon Neutral Pledge. Under review.

57. Sanchez, O.A. Peace with Nature. La Nacion, 2007. Available online: http://www.nacion.com/opinion/Paznaturaleza_0_915508509.html (accessed on 6 November 2015).

58. Blackman, A.; Woodward, R.T. User financing in a national payments for environmental services program: Costa Rican hydropower. Ecol. Econ. 2010, 69, 1626-1638. [CrossRef]

59. Government of Costa Rica: Ministry of Environment and Energy, Costa Rica's Intended Nationally Determined Contribution. Available online: http://www4.unfccc.int/submissions/INDC/Published\% 20Documents / Costa\%20Rica/1/INDC\%20Costa\%20Rica\%20Version\%202\%200\%20final\%20ENG.pdf (accessed on 6 January 2016).

60. Climate Action Tracker: Costa Rica. Available online: http:/ / climateactiontracker.org/countries/costarica. html (accessed on 25 September 2017).

61. Luxner, L. Costa Rica tops Central American ranking in latest climate change adaptation index. The Tico Times, 2014. Available online: http:/ / www.ticotimes.net/2014/11/10/costa-rica-tops-central-american-rankingin-latest-climate-change-adaptation-index (accessed on 26 September 2017).

62. Flagg, J.A. Aiming for Zero: What Makes a Nation Adopt a Carbon Neutral Pledge? Ph.D. Thesis, Rutgers University, New Brunswick, NJ, USA, 2016.

63. Roberts, J.T.; Parks, B.C. A Climate of Injustice: Global Inequality, North-South Politics, and Climate Policy. MIT Press: Cambridge, MA, USA, 2007.

64. Izdebski, A.; Holmgren, K.; Weiberg, E.; Stocker, S.R.; Buntgen, U.; Florenzano, A.; Gogou, A.; Leroy, S.A.G.; Luterbacher, J.; Martrat, B.; et al. Realising consilience: How better communication between archaeologists, historians and natural scientists can transform the study of past climate change in the Mediterranean. Quat. Sci. Rev. 2015, 136, 5-22. [CrossRef]

65. Marignani, M.; Chiarucci, A.; Sadori, L.; Mercuri, A.M. Natural and human impact in Mediterranean landscapes: An intriguing puzzle or only a question of time? Plant Biosyst. 2017, 151, 900-905. [CrossRef]

66. Davies, A.L.; Bunting, M.J. Applications of Paleoecology in Conservation. Open Ecol. J. 2010, 3, 54-67.

(C) 2018 by the author. Licensee MDPI, Basel, Switzerland. This article is an open access article distributed under the terms and conditions of the Creative Commons Attribution (CC BY) license (http://creativecommons.org/licenses/by/4.0/). 